\title{
The Redox-Sensitive Na/K-ATPase Signaling in Uremic Cardiomyopathy
}

\author{
Jiang Liu ${ }^{1, *(\mathbb{D}}$, Ying Nie ${ }^{1}$, Muhammad Chaudhry ${ }^{1}$, Fang Bai ${ }^{1}$, Justin Chuang ${ }^{2}$, Komal Sodhi ${ }^{2}$ (I) \\ and Joseph I. Shapiro ${ }^{2}$ \\ 1 Department of Biomedical Sciences, Joan C. Edwards School of Medicine, Marshall University, \\ Huntington, WV 25755, USA; niey@marshall.edu (Y.N.); chaudhry@marshall.edu (M.C.); \\ baif@marshall.edu (F.B.) \\ 2 Department of Medicine, Joan C. Edwards School of Medicine, Marshall University, \\ Huntington, WV 25755, USA; chuang@marshall.edu (J.C.); sodhi@marshall.edu (K.S.); \\ shapiroj@marshall.edu (J.I.S.) \\ * Correspondence: liujl@marshall.edu
}

Received: 21 January 2020; Accepted: 10 February 2020; Published: 13 February 2020

\begin{abstract}
In recent years, $\mathrm{Na} / \mathrm{K}$-ATPase signaling has been implicated in different physiological and pathophysiological conditions, including cardiac hypertrophy and uremic cardiomyopathy. Cardiotonic steroids (CTS), specific ligands of $\mathrm{Na} / \mathrm{K}$-ATPase, regulate its enzymatic activity (at higher concentrations) and signaling function (at lower concentrations without significantly affecting its enzymatic activity) and increase reactive oxygen species (ROS) generation. On the other hand, an increase in ROS alone also regulates the $\mathrm{Na} / \mathrm{K}$-ATPase enzymatic activity and signaling function. We termed this phenomenon the $\mathrm{Na} / \mathrm{K}$-ATPase-mediated oxidant-amplification loop, in which oxidative stress regulates both the $\mathrm{Na} / \mathrm{K}$-ATPase activity and signaling. Most recently, we also demonstrated that this amplification loop is involved in the development of uremic cardiomyopathy. This review aims to evaluate the redox-sensitive $\mathrm{Na} / \mathrm{K}$-ATPase-mediated oxidant amplification loop and uremic cardiomyopathy.
\end{abstract}

Keywords: Na/K-ATPase; signaling; c-Src. ROS; partial (5/6th) nephrectomy; uremic cardiomyopathy

\section{Introduction}

For 200 years, digitalis-like drugs have been used to treat heart failure. This is based on the facts that digitalis-like drugs cause an inotropic effect by coupling the partial inhibition of the Na/K-ATPase ion-exchange activity (increases intracellular sodium concentration, $\left[\mathrm{Na}^{+}\right]_{i}$ ) with $\mathrm{Na}^{+} / \mathrm{Ca}^{2+}$ exchanger (NCX) (increases intracellular calcium concentration, $\left[\mathrm{Ca}^{2+}\right]_{i}$ ) to increase cardiac contractility. However, further studies were unable to directly link ouabain-mediated gene regulation effects to intracellular ionic change or the homeostasis of sodium and potassium. Later, it was demonstrated that digitalis-like drugs not only cause intracellular ionic changes but also stimulate transcriptional upregulation of several marker genes including $\mathrm{Na} / \mathrm{K}$-ATPase itself, as well as cardiac hypertrophy and cardiac fibrosis through increased cell growth and protein synthesis.

The recently discovered and appreciated $\mathrm{Na} / \mathrm{K}$-ATPase signaling function sheds new light on the understanding of its regulatory mechanism of cardiac function. The ligands of Na/K-ATPase, cardiotonic steroids (CTSs, also known as endogenous digitalis-like substances which are the base of digitalis-like drugs) have been classified as a new class of hormones, making $\mathrm{Na} / \mathrm{K}$-ATPase a potential therapeutic target [1-4]. 


\section{Oxidative Stress and Oxidative Modification in Regulation of Na/K-ATPase Activity}

The redox sensitivity of $\mathrm{Na} / \mathrm{K}$-ATPase has been observed in a wide range of animal species, tissues, and cell types. Increases in reactive oxygen species (ROS) and/or reactive nitrogen species (RNS) can oxidize the $\mathrm{Na} / \mathrm{K}$-ATPase $\alpha / \beta$ subunits and its independent regulator FXYD proteins, including S-glutathionylation, S-nitrosylation, phosphorylation, and carbonylation. These oxidative modifications inhibit the $\mathrm{Na} / \mathrm{K}$-ATPase activity and promote its degradation in different cell types, including cardiac myocytes, vascular smooth muscle cells, and renal proximal tubular cells, amongst others [5-25]. It also appears that the oxidative modifications of Na/K-ATPase are reversible [15,17,21], which means the $\mathrm{Na} / \mathrm{K}$-ATPase activity can be regulated in a redox-sensitive manner. In cardiac myocytes and the pig kidney, oxidative stress induces glutathionylation of the $\mathrm{Na} / \mathrm{K}$-ATPase $\beta 1$ subunit. In the meantime, FXYD proteins can reverse oxidative stress-induced inhibition of $\mathrm{Na} / \mathrm{K}$-ATPase activity by the deglutathionylation of the $\beta 1$ subunit [15].

In the oxidative modifications of $\mathrm{Na} / \mathrm{K}$-ATPase, S-glutathionylation is well documented and reviewed. S-glutathionylation of cysteine residue(s) of the $\mathrm{Na} / \mathrm{K}$-ATPase $\alpha 1 / \beta 1$ subunit may reduce $\alpha 1 / \beta 1$ association, cause conformational change, and block the $\alpha 1$ subunit's intracellular ATP-binding site, leading to the inhibition of its activity $[15,26,27]$.

In rat cerebellar granule cells, $\mathrm{Na} / \mathrm{K}$-ATPase is redox-sensitive with an "optimal redox potential range," where ROS levels out of this "optimal range" inhibit the Na/K-ATPase activity [28]. In the dog kidney, the oxidative modification of $\mathrm{Na} / \mathrm{K}$-ATPase by $\mathrm{H}_{2} \mathrm{O}_{2}$ also reduces cellular sulfhydryl (SH) groups [29] and results in the oligomeric structure of $\mathrm{Na} / \mathrm{K}-\mathrm{ATPase}$ [30]. The number, location, and accessibility of SH groups in $\mathrm{Na} / \mathrm{K}$-ATPase may determine the enzyme's oxidative stability and redox sensitivity $[17,31,32]$. The oxidative modification of $\mathrm{Na} / \mathrm{K}-\mathrm{ATPase}$ can lead to conformational and functional changes $[5-8,12,13,15,16,20,23,24,26,32-35]$.

\section{The $\mathrm{Na} / \mathrm{K}-A T P a s e$ Signaling Function is Redox-Sensitive}

The signaling functions of $\mathrm{Na} / \mathrm{K}-\mathrm{ATPase}$ have been demonstrated in different cell types (such as neonatal and adult myocytes and the renal proximal tubule) as well as in different in vivo animal models [36-40]. As specific ligands and inhibitors of $\mathrm{Na} / \mathrm{K}-\mathrm{ATPase}$, cardiotonic steroids (CTSs, also known as digitalis-like substances) belong to a group of structure-similar compounds, including plant-derived digitalis substances such as digoxin and ouabain, and vertebrate-derived aglycones such as bufalin and marinobufagenin (MBG). Endogenous CTSs were defined as a class of steroid hormones (1) that showed different functions [2-4,41,42]. Endogenously identified ouabain and MBG were widely used in the field to study the $\mathrm{Na} / \mathrm{K}$-ATPase and its signaling functions.

Ouabain-induced increases in $\left[\mathrm{Ca}^{2+}\right]_{\mathrm{i}}$ are also involved in ouabain-stimulated $\mathrm{Na} / \mathrm{K}-\mathrm{ATPase}$ signaling. In renal epithelial cells, low doses of ouabain induce regular, low-frequency $\left[\mathrm{Ca}^{2+}\right]_{i}$ oscillations that lead to NF-kB activation. This process does not depend on the partial inhibition of $\mathrm{Na} / \mathrm{K}$-ATPase using low extracellular $\mathrm{K}^{+}$and the depolarization of cells, but depends on the ouabain-stimulated activation of tyrosine kinase c-Src and phospholipase C $-\gamma$ (PLC- $\gamma$ ) and the formation of $\mathrm{Na} / \mathrm{K}$-ATPase/inositol 1,4,5-trisphosphate receptors (IP3Rs) signaling micro-domain, involving the $\alpha 1 \mathrm{~N}$-terminus motif LKK [43-46]. On the other hand, the lowering of extracellular $\mathrm{K}^{+}$ can activate protein kinases and raise $\left[\mathrm{Ca}^{2+}\right]_{\mathrm{i}}$ in cardiac myocytes [47]. Since the effects of ouabain on c-Src phosphorylation are independent of changes in intracellular ion concentrations [38,47-49], it seems that the ouabain-induced inhibition of $\mathrm{Na} / \mathrm{K}$-ATPase enzymatic activity (at high ouabain concentration) and activation of c-Src-dependent signaling (at low ouabain concentration) are, at least partially, two separate regulatory mechanisms.

In isolated rat (neonatal and/or adult) cardiac myocytes, ouabain-stimulated $\mathrm{Na} / \mathrm{K}$-ATPase signaling increases ROS generation $[34,38,40,50]$. In isolated neonatal myocytes, ouabain-induced generation of ROS is largely prevented by overexpression of a dominant negative Ras, suggesting an ouabain-stimulated, Ras-dependent increase in ROS [38]. While the activation of $\mathrm{Na} / \mathrm{K}-\mathrm{ATPase}$ signaling by its ligands increases ROS, increases in ROS alone also activate the $\mathrm{Na} / \mathrm{K}$-ATPase signaling. 
In cultured cardiac myocytes, exogenously added glucose oxidase (which generates a sustained nontoxic low level of $\mathrm{H}_{2} \mathrm{O}_{2}$ by consuming glucose) activate the $\mathrm{Na} / \mathrm{K}$-ATPase signaling, which is sufficient to stimulate protein synthesis, cell enlargement, and the expression of several hypertrophic marker genes [34].

Ouabain also stimulates the $\mathrm{Na} / \mathrm{K}$-ATPase signaling and ROS generation in other cell types, such as renal proximal tubules [21,22,51-54]. In renal proximal tubule LLC-PK1 cells, Na/K-ATPase is involved in the glucose-oxidase-stimulated activation of the c-Src/ERK1/2 pathway [21,51], and a basal ROS level is required to initiate the ouabain-stimulated $\mathrm{Na} / \mathrm{K}$-ATPase signaling and protein carbonylation of two amino acid residues in the actuator domain of the $\mathrm{Na} / \mathrm{K}$-ATPase $\alpha 1$ subunit [21,22]. Moreover, infusion of MBG causes systemic ROS generation and protein oxidation, which is linked to uremic cardiomyopathy in experimental animals $[55,56]$.

Both c-Src and caveolin-1 (structural protein of caveolae) are critical in the Na/K-ATPase/c-Src signaling. These two proteins are not only redox-sensitive but also critical in the redox-signaling platform formation [57-62]. As mentioned before, a basal level of ROS is required for the ouabain-stimulated $\mathrm{Na} / \mathrm{K}$-ATPase/c-Src signaling activation, protein carbonylation, and trafficking of $\mathrm{Na} / \mathrm{K}-\mathrm{ATPase}$ and NHE3 [21,22]. These observations are in agreement with the observations in clinical trials with antioxidant supplements in that the beneficial effect is controversial and not seen in most clinical trials [63-65]. The balance of the redox status, within a physiological range, may be critical in order to maintain beneficial ROS signaling.

Comparing wild-type (WT) mice with caveolin-1 knockout (cav-1 KO) mice, depletion of caveolin- 1 does not affect the total or plasma membrane abundance of $\mathrm{Na} / \mathrm{K}$-ATPase $\alpha 1$ isoform in cardiac fibroblasts [66], adult cardiomyocytes, and left ventricle lysates [67]. In isolated cardiac fibroblasts, depletion of caveolin-1 increases the $\mathrm{Na} / \mathrm{K}$-ATPase ion-exchange activity as well as basal activities of Src and ERK1/2, but it also suppresses ouabain-induced signal transduction, growth, and collagen production [66]. In isolated adult cardiomyocytes, the ouabain-stimulated activation of phosphoinositide 3-kinase (PI3K)- $\alpha /$ Akt and ERK1/2, interaction of Na/K-ATPase with caveolin-3 and PI3K- $\alpha$, and hypertrophic growth were significantly reduced in cav-1 KO mice, compared to WT mice [67]. Interestingly, in both WT and cav-1 KO mice, the transient infusion of ouabain induces similar positive inotropy in vivo, and ouabain also causes similar dose-dependent contractility in isolated working hearts [67]. The data suggest differential roles of cav-1 in the regulation of ouabain signaling and contractility.

It is worth noting that ouabain also activates the PI3K- $\alpha / \mathrm{Akt} / \beta-\mathrm{GSK} / \mathrm{mTOR}$ (mammalian target of rapamycin (mTOR)) pathway that leads to physiological hypertrophy in cultured adult cardiomyocytes that is different from pathological hypertrophy [68-70].

\section{The Redox-Sensitive Na/K-ATPase Signaling and Na/K-ATPase Signaling-Mediated Oxidant Amplification Loop}

The early studies of the Na/K-ATPase signaling function on cardiac hypertrophy were mostly performed with CTSs, especially ouabain, at low doses that did not cause significant changes in intracellular $\mathrm{Na}^{+}$concentration. Interestingly, ouabain-stimulated $\mathrm{Na} / \mathrm{K}-\mathrm{ATPase}$ signaling also increased ROS generation that was involved in the signaling function, which was independent of changes in intracellular $\mathrm{Ca}^{2+}$ and $\mathrm{Na}^{+}$concentrations, but dependent on Ras activation $[38,50]$. This leads to the question of whether the Na/K-ATPase signaling could be activated by ROS alone, since oxidative modifications are able to induce conformational changes which can lead to the $\mathrm{Na} / \mathrm{K}-\mathrm{ATPase} \alpha 1$ subunit-bound c-Src activation. A bolus of hydrogen peroxide $\left(\mathrm{H}_{2} \mathrm{O}_{2}\right)$ or glucose oxidase (to produce $\mathrm{H}_{2} \mathrm{O}_{2}$ ) stimulates the $\mathrm{Na} / \mathrm{K}$-ATPase signaling in LLC-PK1 cells $[21,22,51]$ and cardiac myocytes [34], while glucose oxidase stimulates the Na/K-ATPase signaling and direct protein carbonylation (Pro222 and Thr224) of the Na/K-ATPase $\alpha 1$ subunit that favors an E-2P conformation of $\mathrm{Na} / \mathrm{K}$-ATPase [21,22]. A single mutation of Pro222 (to alanine) and pretreatment with N-acetyl cysteine (NAC) or vitamin E disrupt ouabain- or glucose-oxidase-induced $\mathrm{Na} / \mathrm{K}$-ATPase/Src signaling 
and protein carboxylation [21,22]. As discussed above, the Na/K-ATPase activity and oxidative modifications could be reversibly regulated [15,16,21,22], and the partners of the Na/K-ATPase signaling, c-Src and caveolin are also redox-sensitive and critical in the redox-signaling platform formation. These observations indicate a feed-forward, redox-sensitive $\mathrm{Na} / \mathrm{K}$-ATPase signaling-mediated oxidant amplification loop stimulated by the activation of the $\mathrm{Na} / \mathrm{K}$-ATPase signaling, i.e., activation of the $\mathrm{Na} / \mathrm{K}$-ATPase signaling (either by ouabain or ROS) generates more ROS, which in turn, further activates the signaling [71] (Figure 1). This amplification loop may play an important role in overall redox regulation. Even though the $\mathrm{Na} / \mathrm{K}$-ATPase signaling-mediated oxidant amplification loop was established in the renal proximal tubule cell, the similarity of the $\mathrm{Na} / \mathrm{K}$-ATPase signaling function in both cardiac myocytes and renal proximal tubule cells suggests that this amplification loop might be shared in both cell types. However, this positive feedback mechanism might chronically desensitize the signaling function and reduce the $\mathrm{Na} / \mathrm{K}$-ATPase ion-transport capability by stimulating $\mathrm{Na} / \mathrm{K}-\mathrm{ATPase} / \mathrm{c}-\mathrm{Src}$ endocytosis [72-74].

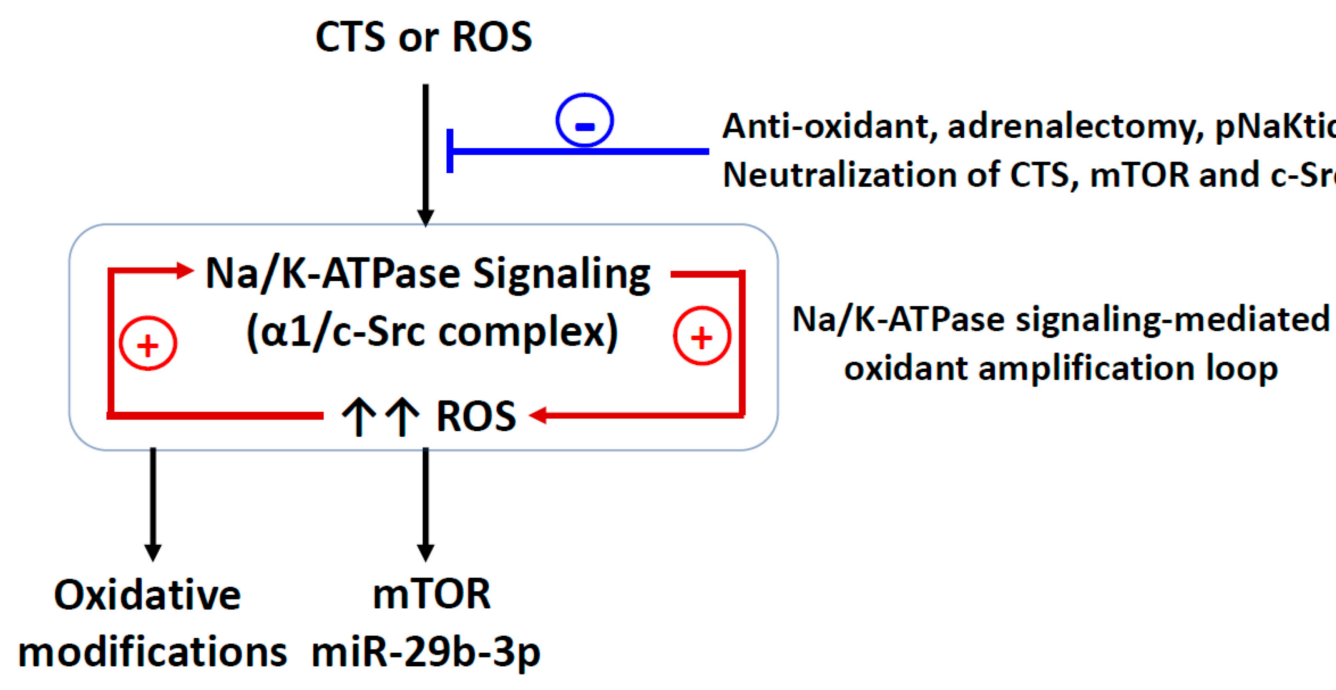

Figure 1. Schematic illustration of the concept of the Na/K-ATPase signaling-mediated oxidant-amplification loop. +, stimulating effect; - attenuating effect; CTS, cardiotonic steroids; ROS, reactive oxygen species; $\alpha 1, \mathrm{Na} / \mathrm{K}-\mathrm{ATPase} \alpha 1$ subunit; mTOR, the mammalian target of rapamycin; miR-29b-3p, microRNA-29b-3p.

\section{The Na/K-ATPase Signaling and Oxidative Stress in Uremic Cardiomyopathy}

Even though it is still not fully understood, clinical evidence supports the existence of a cardio-renal syndrome (worsened cardiac function leads to renal dysfunction) or reno-cardiac syndrome (worsened renal function leads to cardiac dysfunction), in which dysfunction of either the heart or the kidney can lead to pathological changes in both, increased mortality, and comorbidities [75-77]. One example is the development of uremic cardiomyopathy promoted by chronic kidney disease or end-stage renal disease, which has been an increased risk factor of cardiovascular disease and mortality. Uremic cardiomyopathy is characterized by diastolic dysfunction, left ventricular hypertrophy, and fibrosis, and is accompanied by deterioration in left ventricular systolic function and atrial myopathy. Recent studies indicate that endogenous CTSs- and uremic-toxins-induced oxidative stress may play an important role in the uremic cardiomyopathy development, including cardiac hypertrophy and cardiac fibrosis [55,78-88].

CTS-stimulated $\mathrm{Na} / \mathrm{K}$-ATPase signaling induces cardiac and renal fibrosis that can be prevented by ROS scavenging $[38,55,89,90]$. In the kidney and heart, the central role of CTSs in the development of fibrosis has been demonstrated in both in vivo animal models and in vitro cell culture treated with CTSs. Compared to age- and gender-matched healthy controls, in cardiac myocytes isolated from Sprague-Dawley rats, uremic serum samples (collected from end-stage renal disease patients with 
left ventricular hypertrophy and diastolic dysfunction) not only inhibited the Na/K-ATPase activity but also increased contractility and calcium cycling in cardiac myocytes, which can be attenuated by neutralization of the uremic serum samples with Digibind (an antibody fragment against digoxin) [91]. The partial $\left(5 / 6^{\text {th }}\right)$ nephrectomy model ( $\mathrm{PNx}$, a well-documented experimental renal failure model) shows elevated circulating levels of MBG, uremic toxins, systemic oxidant stress, and cardiac fibrosis in both rat and mouse models $[55,87,90,92]$. Active immunization against MBG, administration of an antibody against MBG, or reduction of MBG production by adrenalectomy substantially attenuate PNx- and MBG-infusion-mediated cardiac fibrosis and oxidant stress, an effect that is independent of blood pressure changes $[55,90,93]$.

In rat cardiac and renal fibroblasts, MBG stimulated a PLC-dependent translocation of PKC- $\delta$ to nucleus, resulting in the phosphorylation and degradation of transcription factor Friend leukemia integration-1 (Fli-1), as well as procollagen expression [94]. Both CTS-induced Na/K-ATPase signaling and ROS generation are involved in the development of cardiac and renal fibrosis since CTS-stimulated signaling and fibrosis could be attenuated by ROS scavenging, c-Src inhibition, and competitive inhibition of CTS binding to $\mathrm{Na} / \mathrm{K}-\mathrm{ATP}$ ase by spironolactone and canrenone $[55,90,95,96]$. In LLC-PK1 cells, MBG also stimulates the transcription factor Snail expression, leading to upregulation of collagen I, fibronectin, and vimentin expression, which is associated with epithelial-to-mesenchymal transition (EMT) during renal fibrosis [97].

Patients with chronic kidney disease (CKD) showed higher plasma MBG level compared to healthy people, and PNx rats also showed an increase in the plasma MBG level [82,90]. In Sprague-Dawley rats, PNx or MBG infusion increased plasma MBG levels, blood pressure and heart size, impaired diastolic function, and caused cardiac fibrosis. Interestingly, immunization against MBG prior to PNx surgery and concomitant PNx and adrenalectomy showed similar blood pressure as PNx but fewer changes in cardiac function and fibrosis. In cultured cardiac fibroblasts, MBG induced increases in procollagen- 1 expression that could be prevented by the administration of inhibitors of tyrosine phosphorylation, c-Src activation, EGFR transactivation, and NAC [90]. Administration of a monoclonal antibody against MBG (clone 3E9) 5 weeks post-PNx attenuated PNx-mediated uremic cardiomyopathy, including increased cardiac protein carbonylation, cardiac hypertrophy, collagen-1 expression, and a reduced Fli-1 expression [55,93]. In ex vivo study, the same 3E9 antibody restored $\mathrm{Na} / \mathrm{K}-\mathrm{ATPase}$ in erythrocytes isolated from patients with CKD but did not affect $\mathrm{Na} / \mathrm{K}$-ATPase from control subjects [82]. Furthermore, PNx-mediated cardiomyopathy could be attributed to the $\mathrm{Na} / \mathrm{K}$-ATPase signaling function. The Na/K-ATPase signaling-linked mTOR pathway is involved in the cardiac fibrosis development. Compared to sham, Sprague-Dawley rats with PNx surgery or MBG infusion showed a marked increase in plasma MBG levels, hypertension, and cardiac fibrosis. Rapamycin (a mTORC1 inhibitor) treatment reduced circulating MBG levels in PNx animals, while Rapamycin treatment in combination with MBG infusion significantly attenuated cardiac fibrosis [98].

The $\mathrm{Na} / \mathrm{K}$-ATPase signaling is an important mediator in CKD that regulates microRNA (miR)-29b-3p (an anti-fibrotic microRNA that directly targets the collagen mRNA) expression and cardiac fibrosis. By using $\mathrm{Na} / \mathrm{K}-\mathrm{ATP}$ ase $\alpha 1$ heterozygote knockout mice $(\alpha 1+/-)$ that exhibited a reduction in the $\mathrm{Na} / \mathrm{K}$-ATPase $\alpha 1$ subunit and deficiency in the $\mathrm{Na} / \mathrm{K}$-ATPase signaling, $\alpha 1+/-$ itself potentiated MBG-induced cardiac myocyte apoptosis and cardiac dilation, compared to wild-type (WT) mice [99]. This might be attributed to the MBG-activated c- Src/Akt/mTOR signaling pathway in isolated WT myocytes, but not in $\alpha 1+/-$ myocytes [99]. In cardiac tissue from rats subjected to MBG infusion or PNx, miR-29b-3p expression was consistently reduced in both PNx and MBG-infused animals. Comparing to the control, treatment of primary cultures of adult rat cardiac fibroblasts with MBG induced significant increases in the fibrosis marker and collagen expression, accompanying a concomitant decrease in the miR-29b-3p expression [100]. Further study showed that PNx significantly reduces miR-29b-3p expression in the heart tissue by the activation of c-Src and NFkB signaling in WT mice, but fails to affect the miR-29b-3p expression and Src and NFKB signaling in the $\alpha 1+/$ - mice [101]. 
Among many risk factors, elevated oxidative stress is a significant contributor to inducing cell proliferation, cardiac hypertrophy, and collagen synthesis [50,55,87,90,102,103]. Elevated circulating CTS levels also produce similar phenotypes both in vitro and in vivo $[55,88,104,105]$. In cultured cardiomyocytes, the CTS treatment stimulates ROS generation and NF- $\mathrm{KB}$ activation which could be blocked by pretreatment with antioxidants [50]. CKD patients tend to have increased circulating CTS $[82,83]$ and dilated cardiomyopathy patients tend to have a decreased cardiac $\mathrm{Na} / \mathrm{K}$-ATPase expression [106,107]. In an experimental animal model of PNx and MBG infusion, similar uremic cardiomyopathy phenotypes, such as elevated circulating MBG, cardiac hypertrophy, impaired cardiac function, and cardiac fibrosis, were observed [55,90,108].

In renal proximal tubule cells, a Na/K-ATPase/Src/ROS feed-forward oxidant-amplification loop, which was involved in the $\mathrm{Na} / \mathrm{K}$-ATPase signaling activation and oxidative stress, was demonstrated [21,22]. This oxidant amplification loop was also demonstrated in vivo in the development of uremic cardiomyopathy and provided a potential drug candidate for uremic cardiomyopathy [87]. This observation, using a pole ligation PNx mouse model [109], showed PNx increased c-Src/ERK1/2 phosphorylation along with renal dysfunction, cardiac hypertrophy, cardiac fibrosis, and increased protein carbonylation in the left ventricle. Administration of pNaKtide, an antagonist of the Na/K-ATPase/Src signaling that binds to the c-Src kinase domain [110-112], attenuated physiological, morphological, and biochemical alterations of uremic cardiomyopathy. Interestingly, blockage of this oxidant amplification loop with pNaKtide, but not induction of HO-1, appeared to ameliorate anemia in PNx animals. Taken together, it indicates that the oxidant amplification loop is important for the development of uremic cardiomyopathy (Figure 2). Moreover, this oxidant amplification loop has also been demonstrated to affect other pathophysiological alterations in other types of animal models including the Western diet, obesity, ageing, steatohepatitis, atherosclerosis, and adipogenesis [113-115]. In pre-adipocyte 3T3-L1 cells and MSC-derived adipocytes, uremic toxin indoxyl sulfate and p-cresol sulfate can stimulate the $\mathrm{Na} / \mathrm{K}$-ATPase signaling and the oxidant amplification loop [116], suggesting that this oxidant amplification loop is not limited to one cell type. One of the uremic toxins, asymmetric dimethylarginine (ADMA), is a risk marker for endothelial dysfunction and cardiovascular disease by regulating nitric oxide (NO) generation in disease states. ADMA is a potent competitive inhibitor of nitric oxide synthases and its circulating concentration is increased in the failing kidney(s). An increase in circulating ADMA can lead to reduced heart rate and cardiac output, as well as left ventricular hypertrophy. Thiol containing nitric oxide-derivatives were found to inhibit the brain and kidney Na/K-ATPase activity [26,117]. Moreover, thiol modification can also regulate the interaction between the c-Src and $\alpha 1$ subunit. Cys 458 and 459 form the interaction interface between the $\alpha 1$ subunit and Src kinase and binding of glutathione to Cys 458 and 459 disrupts the interaction [118]. It will be of interest to investigate the effect(s) of ADMA on Na/K-ATPase activity and signaling in the future since it is still not well-understood. 


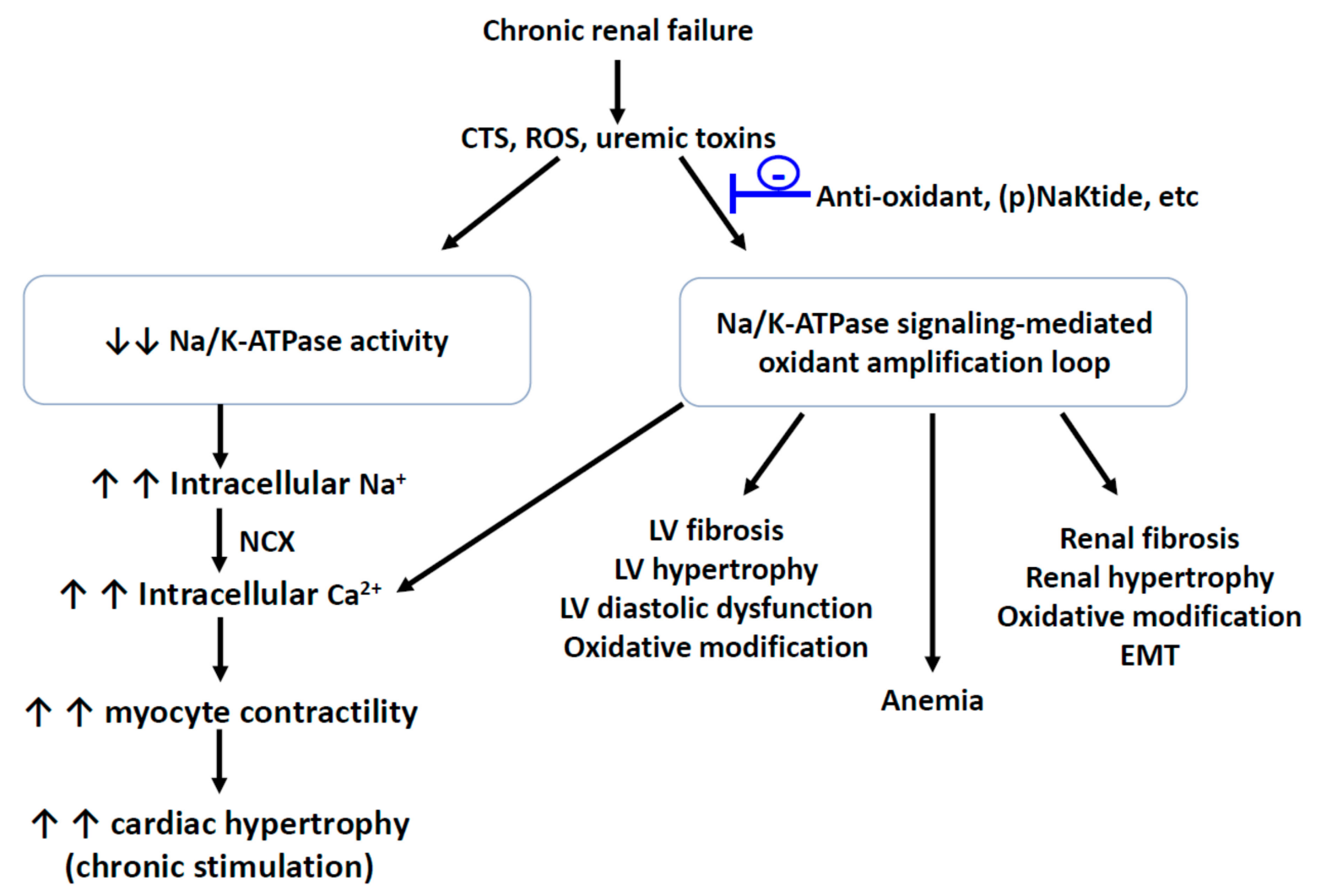

Figure 2. Schematic illustration of the proposed causes and consequences of the $\mathrm{Na} / \mathrm{K}$-ATPase signaling-mediated oxidant amplification loop. - attenuating effect; CTS, cardiotonic steroids; ROS, reactive oxygen species; NCX, sodium/calcium exchanger; EMT, epithelial-to-mesenchymal transition.

\section{Implications and the Possible Role of (p)Naktide}

It appears that the $\mathrm{Na} / \mathrm{K}$-ATPase signaling-mediated oxidant amplification loop contributes to the development of PNx-mediated uremic cardiomyopathy, as well as other pathophysiological changes. Controlling this amplification loop within a physiological range might maintain a beneficial ROS signaling and systemic redox status, making it a promising therapeutic target.

It is worth mentioning that the $(\mathrm{p}) \mathrm{NaKtide}$ might be a promising peptide for the regulation of the $\mathrm{Na} / \mathrm{K}$-ATPase signaling. The binding status of the Na/K-ATPase $\alpha 1$ and c-Src is the centerpiece of the $\mathrm{Na} / \mathrm{K}$-ATPase signaling, in which the $\alpha 1$ subunit provides the ligand-binding sites and the $\alpha 1$-associated c-Src provides the kinase moiety. It was demonstrated that the CD2 and ND1 segments of the $\alpha 1$ subunit bind to the $\mathrm{SH} 2$ domain and tyrosine kinase domain (KD) of c-Src through a two-pair domain binding. NaKtide was developed from the 20-amino acid sequence (SATWLALSRIAGLCNRAVFQ) of the $\alpha 1$ subunit ND1 segment that targets the Na/K-ATPase/c-Src signaling receptor complex and inhibits the $\mathrm{Na} / \mathrm{K}$-ATPase signaling function. $\mathrm{pNaKtide}$ was further developed by adding a 13 -amino acid HIV-TAT leading sequence (GRKKRRQRRRPPQSATWLALSRIAGLCNRAVFQ) to facilitate its cellular permeation. This TAT leading sequence makes the $\mathrm{pNaKtide}$ cell membrane permeable and keeps the pNaKtide to the intracellular face of the cell membrane, which limits the effects of pNaKtide on the membrane-associated (including $\mathrm{Na} / \mathrm{K}-\mathrm{ATPase}-$ associated) c-Src [110-112]. Other than this (at least partial) specificity, pNaKtide affects the basal Src activity much less than that of the specific c-Src inhibitor PP2 (which is a very promising factor that will not eliminate the normal cellular c-Src function), and does not affect IGF-induced ERK activation in cardiac myocytes. Furthermore, pNaKtide is effective in disrupting the formation of the $\mathrm{Na} / \mathrm{K}$-ATPase/Src receptor complex in a dose-dependent manner. Furthermore, pNaKtide blocks the ouabain-induced activation of c-Src and ERK1/2 and hypertrophic growth in cardiac myocytes. Needless to say, it is imperative to further investigate the 
underlying mechanism(s) in which (p)NaKtide controls redox-sensitive $\mathrm{Na} / \mathrm{K}$-ATPase signaling and systemic redox status in cells, tissues, and whole bodies.

Funding: This research was funded by NIH R15 1R15DK106666 (to J. Liu) and NIH RO1 HL071556 (to J.I. Shapiro). Conflicts of Interest: The authors declare no conflict of interest.

$\begin{array}{ll}\text { Abbreviations } \\ \text { CKD } & \text { chronic kidney disease } \\ \text { CTS } & \text { cardiotonic steroids } \\ \text { IP3Rs } & \text { inositol } 1,4,5 \text {-trisphosphate receptors } \\ \text { MBG } & \text { marinobufagenin } \\ \text { NCX } & \mathrm{Na}^{+} / \mathrm{Ca}^{2+} \text { exchanger } \\ \text { PLC- } \gamma & \text { phospholipase } \mathrm{C}-\gamma \gamma \\ \text { PNx } & \text { partial }\left(5 / 6^{\text {th }}\right) \text { nephrectomy } \\ \text { RNS } & \text { reactive nitrogen species } \\ \text { ROS } & \text { reactive oxygen species }\end{array}$

\section{References}

1. Schoner, W. Endogenous cardiac glycosides, a new class of steroid hormones. Eur. J. Biochem. 2002, 269, 2440-2448. [CrossRef] [PubMed]

2. Aperia, A. New roles for an old enzyme: Na,K-ATPase emerges as an interesting drug target. J. Intern. Med. 2007, 261, 44-52. [CrossRef] [PubMed]

3. Bagrov, A.Y.; Shapiro, J.I. Endogenous digitalis: Pathophysiologic roles and therapeutic applications. Nat. Clin. Pract. Nephrol. 2008, 4, 378-392. [CrossRef] [PubMed]

4. Bagrov, A.Y.; Shapiro, J.I.; Fedorova, O.V. Endogenous cardiotonic steroids: Physiology, pharmacology, and novel therapeutic targets. Pharmacol. Rev. 2009, 61, 9-38. [CrossRef] [PubMed]

5. Ellis, D.Z.; Rabe, J.; Sweadner, K.J. Global loss of Na,K-ATPase and its nitric oxide-mediated regulation in a transgenic mouse model of amyotrophic lateral sclerosis. J. Neurosci. 2003, 23, 43-51. [CrossRef] [PubMed]

6. Kim, M.S.; Akera, T. $\mathrm{O}_{2}$ free radicals: Cause of ischemia-reperfusion injury to cardiac Na+-K+-ATPase. Am. J. Physiol. Heart Circ. Physiol. 1987, 252, H252-H257. [CrossRef]

7. Xie, Z.J.; Wang, Y.H.; Askari, A.; Huang, W.H.; Klaunig, J.E. Studies on the specificity of the effects of oxygen metabolites on cardiac sodium pump. J. Mol. Cell. Cardiol. 1990, 22, 911-920. [CrossRef]

8. Huang, W.H.; Wang, Y.; Askari, A. (Na+ + K+)-ATPase: Inactivation and degradation induced by oxygen radicals. Int. J. Biochem. 1992, 24, 621-626.

9. Huang, W.-H.; Wang, Y.; Askari, A.; Zolotarjova, N.; Ganjeizadeh, M. Different sensitivities of the $\mathrm{Na}+\mathrm{K}+$-ATPase isoforms to oxidants. Biochim. Biophys. Acta Biomembr. 1994, 1190, 108-114. [CrossRef]

10. Zolotarjova, N.; Ho, C.; Mellgren, R.L.; Askari, A.; Huang, W.H. Different sensitivities of native and oxidized forms of $\mathrm{Na}+/ \mathrm{K}(+)$-ATPase to intracellular proteinases. Biochim. Biophys. Acta 1994,1192, 125-131. [CrossRef]

11. Xie, Z.; Jack-Hays, M.; Wang, Y.; Periyasamy, S.M.; Blanco, G.; Huang, W.H.; Askari, A. Different oxidant sensitivities of the alpha 1 and alpha 2 isoforms of $\mathrm{Na}+/ \mathrm{K}(+)$-ATPase expressed in baculovirus-infected insect cells. Biochem. Biophys. Res. Commun. 1995, 207, 155-159. [CrossRef] [PubMed]

12. Mense, M.; Stark, G.; Apell, H.J. Effects of free radicals on partial reactions of the Na,K-ATPase. J. Membr. Biol. 1997, 156, 63-71. [CrossRef] [PubMed]

13. Thévenod, F.; Friedmann, J.M. Cadmium-mediated oxidative stress in kidney proximal tubule cells induces degradation of $\mathrm{Na}+/ \mathrm{K}+-\mathrm{ATPase}$ through proteasomal and endo-/lysosomal proteolytic pathways. FASEB J. 1999, 13, 1751-1761. [CrossRef] [PubMed]

14. White, C.N.; Figtree, G.A.; Liu, C.-C.; Garcia, A.; Hamilton, E.J.; Chia KK, M.; Rasmussen, H.H. Angiotensin II inhibits the Na+-K+ pump via PKC-dependent activation of NADPH oxidase. Am. J. Physiol. Cell Physiol. 2009, 296, C693-C700. [CrossRef] [PubMed]

15. Figtree, G.A.; Liu, C.-C.; Bibert, S.; Hamilton, E.J.; Garcia, A.; White, C.N.; Chia KK, M.; Cornelius, F.; Geering, K.; Rasmussen, H.H. Reversible Oxidative Modification: A Key Mechanism of Na+-K+ Pump Regulation. Circ. Res. 2009, 105, 185-193. [CrossRef] [PubMed] 
16. Bibert, S.; Liu, C.-C.; Figtree, G.A.; Garcia, A.; Hamilton, E.J.; Marassi, F.M.; Sweadner, K.J.; Cornelius, F.; Geering, K.; Rasmussen, H.H. FXYD Proteins Reverse Inhibition of the Na+-K+ Pump Mediated by Glutathionylation of Its $\beta 1$ Subunit. J. Biol. Chem. 2011, 286, 18562-18572. [CrossRef] [PubMed]

17. Bogdanova, A.; Petrushanko, I.Y.; Hernansanz-Agustin, P.; Martinez-Ruiz, A. “Oxygen Sensing” by Na,K-ATPase: These Miraculous Thiols. Front. Physiol. 2016, 7, 314. [CrossRef]

18. Comellas, A.P.; Dada, L.A.; Lecuona, E.; Pesce, L.M.; Chandel, N.S.; Quesada, N.; Budinger, G.S.; Strous, G.J.; Ciechanover, A.; Sznajder, J.I. Hypoxia-Mediated Degradation of Na,K-ATPase via Mitochondrial Reactive Oxygen Species and the Ubiquitin-Conjugating System. Circ. Res. 2006, 98, 1314-1322. [CrossRef]

19. Dada, L.A.; Chandel, N.S.; Ridge, K.M.; Pedemonte, C.; Bertorello, A.M.; Sznajder, J.I. Hypoxia-induced endocytosis of $\mathrm{Na}, \mathrm{K}-\mathrm{ATPase}$ in alveolar epithelial cells is mediated by mitochondrial reactive oxygen species

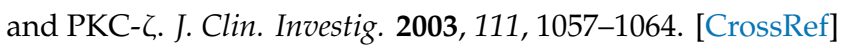

20. Figtree, G.A.; Keyvan Karimi, G.; Liu, C.C.; Rasmussen, H.H. Oxidative regulation of the $\mathrm{Na}(+)-\mathrm{K}(+)$ pump in the cardiovascular system. Free Radic. Biol. Med. 2012, 53, 2263-2268. [CrossRef]

21. Yan, Y.; Shapiro, A.P.; Haller, S.; Katragadda, V.; Liu, L.; Tian, J.; Basrur, V.; Malhotra, D.; Xie, Z.J.; Abraham, N.G.; et al. Involvement of reactive oxygen species in a feed-forward mechanism of $\mathrm{Na} / \mathrm{K}$-ATPase-mediated signaling transduction. J. Biol. Chem. 2013, 288, 34249-34258. [CrossRef] [PubMed]

22. Yan, Y.; Shapiro, A.P.; Mopidevi, B.R.; Chaudhry, M.A.; Maxwell, K.; Haller, S.T.; Drummond, C.A.; Kennedy, D.J.; Tian, J.; Malhotra, D.; et al. Protein Carbonylation of an Amino Acid Residue of the $\mathrm{Na} / \mathrm{K}-\mathrm{ATPase}$ alpha1 Subunit Determines $\mathrm{Na} / \mathrm{K}-\mathrm{ATPase}$ Signaling and Sodium Transport in Renal Proximal Tubular Cells. J. Am. Heart Assoc. 2016, 5, e003675. [CrossRef] [PubMed]

23. Reifenberger, M.S.; Arnett, K.L.; Gatto, C.; Milanick, M.A. The reactive nitrogen species peroxynitrite is a potent inhibitor of renal Na-K-ATPase activity. Am. J. Physiol. Renal Physiol. 2008, 295, F1191-F1198. [CrossRef] [PubMed]

24. Zhang, C.; Imam, S.Z.; Ali, S.F.; Mayeux, P.R. Peroxynitrite and the regulation of Na+,K+-ATPase activity by angiotensin II in the rat proximal tubule. Nitric Oxide 2002, 7, 30-35. [CrossRef]

25. McKenna, M.J.; Medved, I.; Goodman, C.A.; Brown, M.J.; Bjorksten, A.R.; Murphy, K.T.; Petersen, A.C.; Sostaric, S.; Gong, X. N-acetylcysteine attenuates the decline in muscle Na+,K+-pump activity and delays fatigue during prolonged exercise in humans. J. Physiol. 2006, 576, 279-288. [CrossRef]

26. Petrushanko, I.Y.; Yakushev, S.; Mitkevich, V.A.; Kamanina, Y.V.; Ziganshin, R.H.; Meng, X.; Anashkina, A.A.; Makhro, A.; Lopina, O.D.; Gassmann, M.; et al. S-glutathionylation of the Na,K-ATPase catalytic alpha subunit is a determinant of the enzyme redox sensitivity. J. Biol. Chem. 2012, 287, 32195-32205. [CrossRef]

27. Liu, C.-C.; Garcia, A.; Mahmmoud, Y.A.; Hamilton, E.J.; Galougahi, K.K.; Fry, N.A.; Figtree, G.A.; Cornelius, F.; Clarke, R.J.; Rasmussen, H.H. Susceptibility of $\beta 1 \mathrm{Na}+-\mathrm{K}+$ Pump Subunit to Glutathionylation and Oxidative Inhibition Depends on Conformational State of Pump. J. Biol. Chem. 2012, 287, 12353-12364. [CrossRef]

28. Petrushanko, I.; Bogdanov, N.; Bulygina, E.; Grenacher, B.; Leinsoo, T.; Boldyrev, A.; Gassmann, M.; Bogdanova, A. Na-K-ATPase in rat cerebellar granule cells is redox sensitive. Am. J. Physiol. Regul. Integr. Comp. Physiol. 2006, 290, R916-R925. [CrossRef]

29. Boldyrev, A.; Kurella, E. Mechanism of oxidative damage of dog kidney Na/K-ATPase. Biochem. Biophys. Res. Commun. 1996, 222, 483-487. [CrossRef]

30. Dobrota, D.; Matejovicova, M.; Kurella, E.G.; Boldyrev, A.A. Na/K-ATPase under oxidative stress: Molecular mechanisms of injury. Cell. Mol. Neurobiol. 1999, 19, 141-149. [CrossRef]

31. Kurella, E.G.; Tyulina, O.V.; Boldyrev, A.A. Oxidative resistance of Na/K-ATPase. Cell. Mol. Neurobiol. 1999, 19, 133-140. [CrossRef]

32. Bogdanova, A.; Petrushanko, I.; Boldyrev, A.; Gassmann, M. Oxygen- and Redox-Induced Regulation of the $\mathrm{Na} / \mathrm{K}$ ATPase. Curr. Enzyme Inhib. 2006, 2, 37-59. [CrossRef]

33. Soares-da-Silva, P.; Silva, E. Renal Redox Balance and Na+,K+-ATPase Regulation: Role in Physiology and Pathophysiology; Faculty of Medicine: Porto, Portugal, 2012.

34. Liu, L.; Li, J.; Liu, J.; Yuan, Z.; Pierre, S.V.; Qu, W.; Zhao, X.; Xie, Z. Involvement of Na+/K+-ATPase in hydrogen peroxide-induced hypertrophy in cardiac myocytes. Free Radic. Biol. Med. 2006, 41, 1548-1556. [CrossRef]

35. Goldshleger, R.; Karlish, S.J. Fe-catalyzed cleavage of the alpha subunit of Na/K-ATPase: Evidence for conformation-sensitive interactions between cytoplasmic domains. Proc. Natl. Acad. Sci. USA 1997, 94, 9596-9601. [CrossRef] 
36. Barry, W.H.; Hasin, Y.; Smith, T.W. Sodium pump inhibition, enhanced calcium influx via sodium-calcium exchange, and positive inotropic response in cultured heart cells. Circ. Res. 1985, 56, 231-241. [CrossRef]

37. Reuter, H.; Pott, C.; Goldhaber, J.I.; Henderson, S.A.; Philipson, K.D.; Schwinger, R.H. Na(+)-Ca ${ }^{2+}$ exchange in the regulation of cardiac excitation-contraction coupling. Cardiovasc. Res. 2005, 67, 198-207. [CrossRef]

38. Liu, J.; Tian, J.; Haas, M.; Shapiro, J.I.; Askari, A.; Xie, Z. Ouabain interaction with cardiac Na+/K+-ATPase initiates signal cascades independent of changes in intracellular $\mathrm{Na}+$ and $\mathrm{Ca}^{2+}$ concentrations. J. Biol. Chem. 2000, 275, 27838-27844.

39. Tian, J.; Gong, X.; Xie, Z. Signal-transducing function of Na+-K+-ATPase is essential for ouabain's effect on [Ca2+]i in rat cardiac myocytes. Am. J. Physiol. Heart Circ. Physiol. 2001, 281, H1899-H1907. [CrossRef]

40. Tian, J.; Liu, J.; Garlid, K.D.; Shapiro, J.I.; Xie, Z. Involvement of mitogen-activated protein kinases and reactive oxygen species in the inotropic action of ouabain on cardiac myocytes. A potential role for mitochondrial K(ATP) channels. Mol. Cell Biochem. 2003, 242, 181-187. [CrossRef]

41. Schoner, W.; Scheiner-Bobis, G. Endogenous and exogenous cardiac glycosides: Their roles in hypertension, salt metabolism, and cell growth. Am. J. Physiol. Cell Physiol. 2007, 293, C509-C536. [CrossRef]

42. Schoner, W.; Scheiner-Bobis, G. Role of endogenous cardiotonic steroids in sodium homeostasis. Nephrol. Dial. Transplant. 2008, 23, 2723-2729. [CrossRef] [PubMed]

43. Aizman, O.; Uhlen, P.; Lal, M.; Brismar, H.; Aperia, A. Ouabain, a steroid hormone that signals with slow calcium oscillations. Proc. Natl. Acad. Sci. USA 2001, 98, 13420-13424. [CrossRef] [PubMed]

44. Miyakawa-Naito, A.; Uhlen, P.; Lal, M.; Aizman, O.; Mikoshiba, K.; Brismar, H.; Zelenin, S.; Aperia, A. Cell signaling microdomain with $\mathrm{Na}, \mathrm{K}-\mathrm{ATPase}$ and inositol 1,4,5-trisphosphate receptor generates calcium oscillations. J. Biol. Chem. 2003, 278, 50355-50361. [CrossRef] [PubMed]

45. Yuan, Z.; Cai, T.; Tian, J.; Ivanov, A.V.; Giovannucci, D.R.; Xie, Z. Na/K-ATPase tethers phospholipase C and IP3 receptor into a calcium-regulatory complex. Mol. Biol. Cell 2005, 16, 4034-4045. [CrossRef]

46. Chen, Y.; Cai, T.; Yang, C.; Turner, D.A.; Giovannucci, D.R.; Xie, Z. Regulation of Inositol 1,4,5-Trisphosphate Receptor-mediated Calcium Release by the Na/K-ATPase in Cultured Renal Epithelial Cells. J. Biol. Chem. 2008, 283, 1128-1136. [CrossRef]

47. Haas, M.; Askari, A.; Xie, Z. Involvement of Src and epidermal growth factor receptor in the signal-transducing function of $\mathrm{Na}+/ \mathrm{K}+-\mathrm{ATPase}$. J. Biol. Chem. 2000, 275, 27832-27837. [CrossRef]

48. Aydemir-Koksoy, A.; Abramowitz, J.; Allen, J.C. Ouabain-induced signaling and vascular smooth muscle cell proliferation. J. Biol. Chem. 2001, 276, 46605-46611. [CrossRef]

49. Haas, M.; Wang, H.; Tian, J.; Xie, Z. Src-mediated inter-receptor cross-talk between the Na+/K+-ATPase and the epidermal growth factor receptor relays the signal from ouabain to mitogen-activated protein kinases. J. Biol. Chem. 2002, 277, 18694-18702. [CrossRef]

50. Xie, Z.; Kometiani, P.; Liu, J.; Li, J.; Shapiro, J.I.; Askari, A. Intracellular reactive oxygen species mediate the linkage of $\mathrm{Na}+/ \mathrm{K}+-A T P a s e$ to hypertrophy and its marker genes in cardiac myocytes. J. Biol. Chem. 1999, 274, 19323-19328. [CrossRef]

51. Wang, Y.; Ye, Q.; Liu, C.; Xie, J.X.; Yan, Y.; Lai, F.; Duan, Q.; Li, X.; Tian, J.; Xie, Z. Involvement of Na/K-ATPase in hydrogen peroxide-induced activation of the Src/ERK pathway in LLC-PK1 cells. Free Radic. Biol. Med. 2014, 71, 415-426. [CrossRef]

52. Kajikawa, M.; Fujimoto, S.; Tsuura, Y.; Mukai, E.; Takeda, T.; Hamamoto, Y.; Takehiro, M.; Fujita, J.; Yamada, Y.; Seino, Y. Ouabain Suppresses Glucose-Induced Mitochondrial ATP Production and Insulin Release by Generating Reactive Oxygen Species in Pancreatic Islets. Diabetes 2002, 51, 2522-2529. [CrossRef] [PubMed]

53. Huang, Y.T.; Chueh, S.C.; Teng, C.M.; Guh, J.H. Investigation of ouabain-induced anticancer effect in human androgen-independent prostate cancer PC-3 cells. Biochem. Pharmacol. 2004, 67, 727-733. [CrossRef] [PubMed]

54. Boldyrev, A.; Bulygina, E.; Yuneva, M.; Schoner, W. Na/K-ATPase regulates intracellular ROS level in cerebellum neurons. Ann. N. Y. Acad. Sci. 2003, 986, 519-521. [CrossRef] [PubMed]

55. Kennedy, D.J.; Vetteth, S.; Periyasamy, S.M.; Kanj, M.; Fedorova, L.; Khouri, S.; Kahaleh, M.B.; Xie, Z.; Malhotra, D.; Kolodkin, N.I.; et al. Central role for the cardiotonic steroid marinobufagenin in the pathogenesis of experimental uremic cardiomyopathy. Hypertension 2006, 47, 488-495. [CrossRef] [PubMed] 
56. Kennedy, D.J.; Vetteth, S.; Xie, M.; Periyasamy, S.M.; Xie, Z.; Han, C.; Basrur, V.; Mutgi, K.; Fedorov, V.; Malhotra, D.; et al. Ouabain decreases sarco(endo)plasmic reticulum calcium ATPase activity in rat hearts by a process involving protein oxidation. Am. J. Physiol. Heart Circ. Physiol. 2006, 291, H3003-H3011. [CrossRef] [PubMed]

57. Zhang, A.Y.; Yi, F.; Zhang, G.; Gulbins, E.; Li, P.-L. Lipid Raft Clustering and Redox Signaling Platform Formation in Coronary Arterial Endothelial Cells. Hypertension 2006, 47, 74-80. [CrossRef]

58. Zuo, L.; Ushio-Fukai, M.; Ikeda, S.; Hilenski, L.; Patrushev, N.; Alexander, R.W. Caveolin-1 Is Essential for Activation of Rac1 and NAD(P)H Oxidase After Angiotensin II Type 1 Receptor Stimulation in Vascular Smooth Muscle Cells: Role in Redox Signaling and Vascular Hypertrophy. Arterioscler. Thromb. Vasc. Biol. 2005, 25, 1824-1830. [CrossRef]

59. Touyz, R.M. Lipid Rafts Take Center Stage in Endothelial Cell Redox Signaling by Death Receptors. Hypertension 2006, 47, 16-18. [CrossRef]

60. Han, W.; Li, H.; Villar, V.A.M.; Pascua, A.M.; Dajani, M.I.; Wang, X.; Natarajan, A.; Quinn, M.T.; Felder, R.A.; Jose, P.A.; et al. Lipid Rafts Keep NADPH Oxidase in the Inactive State in Human Renal Proximal Tubule Cells. Hypertension 2008, 51, 481-487. [CrossRef]

61. Seshiah, P.N.; Weber, D.S.; Rocic, P.; Valppu, L.; Taniyama, Y.; Griendling, K.K. Angiotensin II Stimulation of NAD(P)H Oxidase Activity. Circ. Res. 2002, 91, 406-413. [CrossRef]

62. Touyz, R.M.; Yao, G.; Schiffrin, E.L. c-Src induces phosphorylation and translocation of p47phox: Role in superoxide generation by angiotensin II in human vascular smooth muscle cells. Arterioscler. Thromb. Vasc. Biol. 2003, 23, 981-987. [CrossRef] [PubMed]

63. Touyz, R.M. Reactive oxygen species, vascular oxidative stress, and redox signaling in hypertension: What is the clinical significance? Hypertension 2004, 44, 248-252. [CrossRef] [PubMed]

64. Munzel, T.; Gori, T.; Bruno, R.M.; Taddei, S. Is oxidative stress a therapeutic target in cardiovascular disease? Eur. Heart J. 2010, 31, 2741-2748. [CrossRef] [PubMed]

65. Huang, H.-Y.; Caballero, B.; Chang, S.; Alberg, A.J.; Semba, R.D.; Schneyer, C.R.; Wilson, R.F.; Cheng, T.-Y.; Vassy, J.; Prokopowicz, G.; et al. The Efficacy and Safety of Multivitamin and Mineral Supplement Use To Prevent Cancer and Chronic Disease in Adults: A Systematic Review for a National Institutes of Health State-of-the-Science Conference. Ann. Intern. Med. 2006, 145, 372-385. [CrossRef]

66. Quintas, L.E.; Pierre, S.V.; Liu, L.; Bai, Y.; Liu, X.; Xie, Z.J. Alterations of Na+/K+-ATPase function in caveolin-1 knockout cardiac fibroblasts. J. Mol. Cell. Cardiol. 2010, 49, 525-531. [CrossRef]

67. Bai, Y.; Wu, J.; Li, D.; Morgan, E.E.; Liu, J.; Zhao, X.; Walsh, A.; Saikumar, J.; Tinkel, J.; Joe, B.; et al. Differential roles of caveolin-1 in ouabain-induced $\mathrm{Na}+/ \mathrm{K}+-\mathrm{ATPase}$ cardiac signaling and contractility. Physiol. Genom. 2016, 48, 739-748. [CrossRef]

68. Liu, L.; Zhao, X.; Pierre, S.V.; Askari, A. Association of PI3K-Akt signaling pathway with digitalis-induced hypertrophy of cardiac myocytes. Am. J. Physiol. Cell Physiol. 2007, 293, C1489-C1497. [CrossRef]

69. Bai, Y.; Morgan, E.E.; Giovannucci, D.R.; Pierre, S.V.; Philipson, K.D.; Askari, A.; Liu, L. Different roles of the cardiac $\mathrm{Na}+/ \mathrm{Ca}^{2+}$-exchanger in ouabain-induced inotropy, cell signaling, and hypertrophy. Am. J. Physiol. Heart Circ. Physiol. 2013, 304, H427-H435. [CrossRef]

70. Wu, J.; Li, D.; Du, L.; Baldawi, M.; Gable, M.E.; Askari, A.; Liu, L. Ouabain prevents pathological cardiac hypertrophy and heart failure through activation of phosphoinositide 3-kinase alpha in mouse. Cell Biosci. 2015, 5, 64. [CrossRef]

71. Pratt, R.D.; Brickman, C.R.; Cottrill, C.L.; Shapiro, J.I.; Liu, J. The Na/K-ATPase Signaling: From Specific Ligands to General Reactive Oxygen Species. Int. J. Mol. Sci. 2018, 19, 2600. [CrossRef]

72. Liu, J.; Kesiry, R.; Periyasamy, S.M.; Malhotra, D.; Xie, Z.; Shapiro, J.I. Ouabain induces endocytosis of plasmalemmal Na/K-ATPase in LLC-PK1 cells by a clathrin-dependent mechanism. Kidney Int. 2004, 66, 227-241. [CrossRef] [PubMed]

73. Liu, J.; Liang, M.; Liu, L.; Malhotra, D.; Xie, Z.; Shapiro, J.I. Ouabain-induced endocytosis of the plasmalemmal $\mathrm{Na} / \mathrm{K}-\mathrm{ATPase}$ in LLC-PK1 cells requires caveolin-1. Kidney Int. 2005, 67, 1844-1854. [CrossRef] [PubMed]

74. Cai, H.; Wu, L.; Qu, W.; Malhotra, D.; Xie, Z.; Shapiro, J.I.; Liu, J. Regulation of apical NHE3 trafficking by ouabain-induced activation of the basolateral $\mathrm{Na}+\mathrm{K}+-\mathrm{ATPase}$ receptor complex. Am. J. Physiol. Cell Physiol. 2008, 294, C555-C563. [CrossRef] [PubMed]

75. Bock, J.S.; Gottlieb, S.S. Cardiorenal syndrome: New perspectives. Circulation 2010, 121, 2592-2600. [CrossRef] 
76. Ronco, C.; Haapio, M.; House, A.A.; Anavekar, N.; Bellomo, R. Cardiorenal syndrome. J. Am. Coll. Cardiol. 2008, 52, 1527-1539. [CrossRef]

77. House, A.A.; Anand, I.; Bellomo, R.; Cruz, D.; Bobek, I.; Anker, S.D.; Aspromonte, N.; Bagshaw, S.; Berl, T.; Daliento, L.; et al. Definition and classification of Cardio-Renal Syndromes: Workgroup statements from the 7th ADQI Consensus Conference. Nephrol. Dial. Transplant. 2010, 25, 1416-1420. [CrossRef]

78. Wang, X.; Shapiro, J.I. Evolving concepts in the pathogenesis of uraemic cardiomyopathy. Nat. Rev. Nephrol. 2019, 15, 159-175. [CrossRef]

79. Winchester, J.F.; Audia, P.F. Extracorporeal strategies for the removal of middle molecules. Semin. Dial. 2006, 19, 110-114. [CrossRef]

80. Lekawanvijit, S.; Kompa, A.R.; Manabe, M.; Wang, B.H.; Langham, R.G.; Nishijima, F.; Kelly, D.J.; Krum, H. Chronic kidney disease-induced cardiac fibrosis is ameliorated by reducing circulating levels of a non-dialysable uremic toxin, indoxyl sulfate. PLoS ONE 2012, 7, e41281. [CrossRef]

81. Mohmand, B.; Malhotra, D.K.; Shapiro, J.I. Uremic cardiomyopathy: Role of circulating digitalis like substances. Front. Biosci. 2005, 10, 2036-2044. [CrossRef]

82. Kolmakova, E.V.; Haller, S.T.; Kennedy, D.J.; Isachkina, A.N.; Budny, G.V.; Frolova, E.V.; Piecha, G.; Nikitina, E.R.; Malhotra, D.; Fedorova, O.V.; et al. Endogenous cardiotonic steroids in chronic renal failure. Nephrol. Dial. Transplant. 2011, 26, 2912-2919. [CrossRef]

83. Komiyama, Y.; Dong, X.H.; Nishimura, N.; Masaki, H.; Yoshika, M.; Masuda, M.; Takahashi, H. A novel endogenous digitalis, telocinobufagin, exhibits elevated plasma levels in patients with terminal renal failure. Clin. Biochem. 2005, 38, 36-45. [CrossRef] [PubMed]

84. Manunta, P.; Stella, P.; Rivera, R.; Ciurlino, D.; Cusi, D.; Ferrandi, M.; Hamlyn, J.M.; Bianchi, G. Left ventricular mass, stroke volume, and ouabain-like factor in essential hypertension. Hypertension 1999, 34, 450-456. [CrossRef] [PubMed]

85. Kennedy, D.J.; Shrestha, K.; Sheehey, B.; Li, X.S.; Guggilam, A.; Wu, Y.; Finucan, M.; Gabi, A.; Medert, C.M.; Westfall, K.; et al. Elevated Plasma Marinobufagenin, An Endogenous Cardiotonic Steroid, Is Associated With Right Ventricular Dysfunction and Nitrative Stress in Heart Failure. Circ. Heart Fail. 2015, 8, 1068-1076. [CrossRef] [PubMed]

86. Bagrov, A.Y.; Fedorova, O.V.; Dmitrieva, R.I.; Howald, W.N.; Hunter, A.P.; Kuznetsova, E.A.; Shpen, V.M. Characterization of a urinary bufodienolide $\mathrm{Na}+, \mathrm{K}+$-ATPase inhibitor in patients after acute myocardial infarction. Hypertension 1998, 31, 1097-1103. [CrossRef]

87. Liu, J.; Tian, J.; Chaudhry, M.; Maxwell, K.; Yan, Y.; Wang, X.; Shah, P.T.; Khawaja, A.A.; Martin, R.; Robinette, T.J.; et al. Attenuation of Na/K-ATPase Mediated Oxidant Amplification with pNaKtide Ameliorates Experimental Uremic Cardiomyopathy. Sci. Rep. 2016, 6, 34592. [CrossRef]

88. Drummond, C.A.; Sayed, M.; Evans, K.L.; Shi, H.; Wang, X.; Haller, S.T.; Liu, J.; Cooper, C.J.; Xie, Z.; Shapiro, J.I.; et al. Reduction of Na/K-ATPase affects cardiac remodeling and increases c-kit cell abundance in partial nephrectomized mice. Am. J. Physiol. Heart Circ. Physiol. 2014, 306, H1631-H1643. [CrossRef]

89. Priyadarshi, S.; Valentine, B.; Han, C.; Fedorova, O.V.; Bagrov, A.Y.; Liu, J.; Periyasamy, S.M.; Kennedy, D.; Malhotra, D.; Xie, Z.; et al. Effect of green tea extract on cardiac hypertrophy following 5/6 nephrectomy in the rat. Kidney Int. 2003, 63, 1785-1790. [CrossRef]

90. Elkareh, J.; Kennedy, D.J.; Yashaswi, B.; Vetteth, S.; Shidyak, A.; Kim, E.G.; Smaili, S.; Periyasamy, S.M.; Hariri, I.M.; Fedorova, L.; et al. Marinobufagenin stimulates fibroblast collagen production and causes fibrosis in experimental uremic cardiomyopathy. Hypertension 2007, 49, 215-224. [CrossRef]

91. Periyasamy, S.M.; Chen, J.; Cooney, D.; Carter, P.; Omran, E.; Tian, J.; Priyadarshi, S.; Bagrov, A.; Fedorova, O.; Malhotra, D.; et al. Effects of uremic serum on isolated cardiac myocyte calcium cycling and contractile function. Kidney Int. 2001, 60, 2367-2376. [CrossRef]

92. Kennedy, D.J.; Elkareh, J.; Shidyak, A.; Shapiro, A.P.; Smaili, S.; Mutgi, K.; Gupta, S.; Tian, J.; Morgan, E.; Khouri, S.; et al. Partial nephrectomy as a model for uremic cardiomyopathy in the mouse. Am. J. Physiol. Renal Physiol. 2008, 294, F450-F454. [CrossRef] [PubMed]

93. Haller, S.T.; Kennedy, D.J.; Shidyak, A.; Budny, G.V.; Malhotra, D.; Fedorova, O.V.; Shapiro, J.I.; Bagrov, A.Y. Monoclonal antibody against marinobufagenin reverses cardiac fibrosis in rats with chronic renal failure. Am. J. Hypertens. 2012, 25, 690-696. [CrossRef] [PubMed] 
94. Elkareh, J.; Periyasamy, S.M.; Shidyak, A.; Vetteth, S.; Schroeder, J.; Raju, V.; Hariri, I.M.; El-Okdi, N.; Gupta, S.; Fedorova, L.; et al. Marinobufagenin induces increases in procollagen expression in a process involving protein kinase C and Fli-1: Implications for uremic cardiomyopathy. Am. J. Physiol. Renal Physiol. 2009, 296, F1219-F1226. [CrossRef] [PubMed]

95. Tian, J.; Shidyak, A.; Periyasamy, S.M.; Haller, S.; Taleb, M.; El-Okdi, N.; Elkareh, J.; Gupta, S.; Gohara, S.; Fedorova, O.V.; et al. Spironolactone attenuates experimental uremic cardiomyopathy by antagonizing marinobufagenin. Hypertension 2009, 54, 1313-1320. [CrossRef]

96. El-Okdi, N.; Smaili, S.; Raju, V.; Shidyak, A.; Gupta, S.; Fedorova, L.; Elkareh, J.; Periyasamy, S.; Shapiro, A.P.; Kahaleh, M.B.; et al. Effects of cardiotonic steroids on dermal collagen synthesis and wound healing. J. Appl. Physiol. 2008, 105, 30-36. [CrossRef]

97. Fedorova, L.V.; Raju, V.; El-Okdi, N.; Shidyak, A.; Kennedy, D.J.; Vetteth, S.; Giovannucci, D.R.; Bagrov, A.Y.; Fedorova, O.V.; Shapiro, J.I.; et al. The cardiotonic steroid hormone marinobufagenin induces renal fibrosis: Implication of epithelial-to-mesenchymal transition. Am. J. Physiol. Renal Physiol. 2009, 296, F922-F934. [CrossRef]

98. Haller, S.T.; Yan, Y.; Drummond, C.A.; Xie, J.; Tian, J.; Kennedy, D.J.; Shilova, V.Y.; Xie, Z.; Liu, J.; Cooper, C.J.; et al. Rapamycin Attenuates Cardiac Fibrosis in Experimental Uremic Cardiomyopathy by Reducing Marinobufagenin Levels and Inhibiting Downstream Pro-Fibrotic Signaling. J. Am. Heart Assoc. 2016, 5, e004106. [CrossRef]

99. Liu, C.; Bai, Y.; Chen, Y.; Wang, Y.; Sottejeau, Y.; Liu, L.; Li, X.; Lingrel, J.B.; Malhotra, D.; Cooper, C.J.; et al. Reduction of $\mathrm{Na} / \mathrm{K}-\mathrm{ATPase}$ Potentiates Marinobufagenin-induced Cardiac Dysfunction and Myocyte Apoptosis. J. Biol. Chem. 2012, 287, 16390-16398. [CrossRef]

100. Drummond, C.A.; Hill, M.C.; Shi, H.; Fan, X.; Xie, J.X.; Haller, S.T.; Kennedy, D.J.; Liu, J.; Garrett, M.R.; Xie, Z.; et al. $\mathrm{Na} / \mathrm{K}-\mathrm{ATP}$ ase signaling regulates collagen synthesis through microRNA-29b-3p in cardiac fibroblasts. Physiol. Genom. 2016, 48, 220-229. [CrossRef]

101. Drummond, C.A.; Fan, X.; Haller, S.T.; Kennedy, D.J.; Liu, J.; Tian, J. Na/K-ATPase signaling mediates miR-29b-3p regulation and cardiac fibrosis formation in mice with chronic kidney disease. PLoS ONE 2018, 13, e0197688. [CrossRef]

102. Taylor, D.; Bhandari, S.; Seymour, A.M. Mitochondrial dysfunction in uremic cardiomyopathy. Am. J. Physiol. Renal Physiol. 2015, 308, F579-F587. [CrossRef] [PubMed]

103. Small, D.M.; Coombes, J.S.; Bennett, N.; Johnson, D.W.; Gobe, G.C. Oxidative stress, anti-oxidant therapies and chronic kidney disease. Nephrology 2012, 17, 311-321. [CrossRef] [PubMed]

104. Ferrandi, M.; Molinari, I.; Barassi, P.; Minotti, E.; Bianchi, G.; Ferrari, P. Organ hypertrophic signaling within caveolae membrane subdomains triggered by ouabain and antagonized by PST 2238. J. Biol. Chem. 2004, 279, 33306-33314. [CrossRef] [PubMed]

105. Huang, L.; Li, H.; Xie, Z. Ouabain-induced hypertrophy in cultured cardiac myocytes is accompanied by changes in expression of several late response genes. J. Mol. Cell. Cardiol. 1997, 29, 429-437. [CrossRef] [PubMed]

106. Norgaard, A.; Bagger, J.P.; Bjerregaard, P.; Baandrup, U.; Kjeldsen, K.; Thomsen, P.E. Relation of left ventricular function and $\mathrm{Na}$,K-pump concentration in suspected idiopathic dilated cardiomyopathy. Am. J. Cardiol. 1988, 61, 1312-1315. [CrossRef]

107. Schwinger, R.H.; Bundgaard, H.; Muller-Ehmsen, J.; Kjeldsen, K. The Na, K-ATPase in the failing human heart. Cardiovasc. Res. 2003, 57, 913-920. [CrossRef]

108. Kennedy, D.; Omran, E.; Periyasamy, S.M.; Nadoor, J.; Priyadarshi, A.; Willey, J.C.; Malhotra, D.; Xie, Z.; Shapiro, J.I. Effect of chronic renal failure on cardiac contractile function, calcium cycling, and gene expression of proteins important for calcium homeostasis in the rat. J. Am. Soc. Nephrol. 2003, 14, 90-97. [CrossRef]

109. Wang, X.; Chaudhry, M.A.; Nie, Y.; Xie, Z.; Shapiro, J.I.; Liu, J. A Mouse 5/6th Nephrectomy Model That Induces Experimental Uremic Cardiomyopathy. JoVE 2017, 129, e55825.

110. Li, Z.; Cai, T.; Tian, J.; Xie, J.X.; Zhao, X.; Liu, L.; Shapiro, J.I.; Xie, Z. NaKtide, a Na/K-ATPase-derived peptide Src inhibitor, antagonizes ouabain-activated signal transduction in cultured cells. J. Biol. Chem. 2009, 284, 21066-21076. [CrossRef]

111. Li, Z.; Xie, Z. The Na/K-ATPase/Src complex and cardiotonic steroid-activated protein kinase cascades. Pflug. Arch. 2009, 457, 635-644. [CrossRef] 
112. Li, Z.; Zhang, Z.; Xie, J.X.; Li, X.; Tian, J.; Cai, T.; Cui, H.; Ding, H.; Shapiro, J.I.; Xie, Z. Na/K-ATPase mimetic pNaKtide peptide inhibits the growth of human cancer cells. J. Biol. Chem. 2011, 286, 32394-32403. [CrossRef] [PubMed]

113. Pratt, R.D.; Brickman, C.; Nawab, A.; Cottrill, C.; Snoad, B.; Lakhani, H.V.; Jelcick, A.; Henderson, B.; Bhardwaj, N.N.; Sanabria, J.R.; et al. The Adipocyte Na/K-ATPase Oxidant Amplification Loop is the Central Regulator of Western Diet-Induced Obesity and Associated Comorbidities. Sci. Rep. 2019, 9, 7927. [CrossRef] [PubMed]

114. Sodhi, K.; Nichols, A.; Mallick, A.; Klug, R.L.; Liu, J.; Wang, X.; Srikanthan, K.; Goguet-Rubio, P.; Nawab, A.; Pratt, R.; et al. The Na/K-ATPase Oxidant Amplification Loop Regulates Aging. Sci. Rep. 2018, 8, 9721. [CrossRef] [PubMed]

115. Sodhi, K.; Srikanthan, K.; Goguet-Rubio, P.; Nichols, A.; Mallick, A.; Nawab, A.; Martin, R.; Shah, P.T.; Chaudhry, M.; Sigdel, S.; et al. pNaKtide Attenuates Steatohepatitis and Atherosclerosis by Blocking $\mathrm{Na} / \mathrm{K}-\mathrm{ATPase} / \mathrm{ROS}$ Amplification in C57Bl6 and ApoE Knockout Mice Fed a Western Diet. Sci. Rep. 2017, 7, 193. [CrossRef]

116. Bartlett, D.E.; Miller, R.B.; Thiesfeldt, S.; Lakhani, H.V.; Khanal, T.; D Pratt, R.; Cottrill, C.L.; Klug, R.L.; Adkins, N.S.; Bown, P.C.; et al. Uremic Toxins Activates Na/K-ATPase Oxidant Amplification Loop Causing Phenotypic Changes in Adipocytes in In Vitro Models. Int. J. Mol. Sci. 2018, 19, 2685. [CrossRef]

117. Boldyrev, A.A.; Bulygina, E.R.; Kramarenko, G.G.; Vanin, A.F. Effect of nitroso compounds on Na/K-ATPase. Biochim. Biophys. Acta Bioenerg. 1997, 1321, 243-251. [CrossRef]

118. Petrushanko, I.Y.; Mitkevich, V.A.; Lakunina, V.A.; Anashkina, A.A.; Spirin, P.V.; Rubtsov, P.M.; Prassolov, V.S.; Bogdanov, N.B.; Hanggi, P.; Fuller, W.; et al. Cysteine residues 244 and 458-459 within the catalytic subunit of $\mathrm{Na}, \mathrm{K}-\mathrm{ATPase}$ control the enzyme's hydrolytic and signaling function under hypoxic conditions. Redox Biol. 2017, 13, 310-319. [CrossRef]

(C) 2020 by the authors. Licensee MDPI, Basel, Switzerland. This article is an open access article distributed under the terms and conditions of the Creative Commons Attribution (CC BY) license (http://creativecommons.org/licenses/by/4.0/). 